\title{
THE CONDITIONS OF DWELLINGS MARKET UNDER TRANSITION - A CASE OF POLAND
}

\section{Maria Trojanek}

Abstract Dwelling market policy ran In Poland from the beginning of the 90, based on dominant role of government financing has lead to below mentioned results:

$\checkmark$ Significant lack of available dwellings,

$\checkmark$ Poor quality of supply linked with its decapitalization,

$\checkmark$ Low hire rates which didn't allow to cover maintenance of dwellings' resources,

$\checkmark$ Hire rates were government regulated, so they didn't cover cost of living.

This policy turned out to be ineffective. The market changes implemented in the economy were applied also to dwellings sector-they became market good instead of social privilege, which was subject to all rules of buying, selling, pricing and financing as all market goods This resulted in need of changes aimed at:

1) Improving of low cost, long term credit availability,

2) Designing of government aid for low income citizens in order to help them solve accommodation problem

Some of legal regulations aimed at solving this problem were implemented starting 1994, however the long run plan of dwellings policy was not designed.

The paper contains diagnosis of dwellings' market in Poland under transition and an attempt to identify its development factors.

Keywords: residential market, housing construction 